Palotai, Jenő, Viktor Wetzl, Ákos Jarjabka. "Identity Preservation and Hungarian Language Education in Diaspora Communities." Hungarian Cultural Studies. e-Journal of the American Hungarian Educators Association, Volume 12 (2019) DOI: 10.5195/ahea.2019.353

\title{
Identity Preservation and Hungarian Language Education in Diaspora Communities
}

\author{
Jenő Palotai, Viktor Wetzl, Ákos Jarjabka
}

\begin{abstract}
The main aim of our research is to provide an overview of what role language education plays in how Hungarians living in diaspora communities preserve their cultural identity. To this end we compared three Hungarian schools from three continents (North America, South America and Australia), selected by a sampling based on geographical location. We compared the similarities and differences between their educational methods according to factors predetermined by the research group. By reviewing the extant, but limited literature on this topic, the authors studied the present situation of Hungarians living abroad and the actual questions of identity preservation with special regard to language learning and preservation. These results present a detailed image of language education within the Hungarian diaspora. We also compared the educational methodology employed by the three schools based on different statistical data, such as the number of students, their cohort, student motivation as well as the role of partner institutions in the preservation of Hungarian identity. This study introduces the similarities and differences among institutions located far from one another. The main differences concerned the number of students and their motivation. We aim to give an overview of the current situation while discussing the challenges these communities face and possible opportunities for the continued preservation of their cultural identity.
\end{abstract}

Keywords: Hungarian diaspora, identity preservation, language education, Hungarian school

Biographies: Jenő Palotai earned his BSc degree at the University of Pécs, at the Faculty of Business and Economics of Management in the field of project management. He completed his MSc degree in the area of talent management. Since 2015, he has been a PhD student specializing in the topic of political geography, cultural geography and geopolitics at the Doctoral School of Earth Sciences at the Department of Political Geography, Development and Regional Studies. His publications encompass Hungarian culture, cross border studies and Hungarian minority research. palotai.jeno@gmail.com

Viktor Wetzl earned his BSc degree at the Faculty of Sciences at the University of Pécs's, Institute of Geography in the field of regional and urban development. He attained his MSc degree in the topic of tourism geography and regional development. Since 2015, he has been a $\mathrm{PhD}$ student in the topic of political geography, cultural geography and geopolitics at the Doctoral School of Earth Sciences at the Department of Political Geography, Development and Regional Studies. His publications encompass tourism development, Hungarian culture, cross border studies and Hungarian cultural historical geography.viktorwetzl@gmail.com

Ákos Jarjabka is an Associate Professor at the University of Pécs, Faculty of Business and Economics where he received his PhD in 2004. Since 2013, he has been the head of the Department of Leadership and Organizational Sciences. His publications encompass the science of leadership, international management and project management. Since 2005, he has been a member of the Hungarian Academy of Sciences. He is the leader of the University of Pécs Diaspora Program.akos@ktk.pte.hu

$(\mathrm{cc}) \mathrm{BY}$ ULLS D-Senke 
Palotai, Jenő, Viktor Wetzl, Ákos Jarjabka. "Identity Preservation and Hungarian Language Education in Diaspora Communities." Hungarian Cultural Studies. e-Journal of the American Hungarian Educators Association, Volume 12 (2019) DOI: 10.5195/ahea.2019.353

The aim of our research is to analyze Hungarian identity preservation by examining Hungarian language education in diaspora populations. The objective to analyzing this topic was formulated by the authors in the course of data collecting field work conducted within different Hungarian diaspora communities. The collected primary data was analyzed via empirical experience and contextualized with the aid of the available literature discussing this topic. During the research process, three Hungarian schools were chosen via the method of geographical sampling with a focus on the Hungarian language education provided in the institution and the students' motivation and attitudes. We also compared activities that target identity preservation, educational methods, output requirements and the motivation of the students at these schools, thereby providing the reader with a comprehensive image of how Hungarian identity is preserved across three different continents. Other than the survey of the related literature and statistical data, the basic method employed in this research project consisted of interviewing subjects via the technique of semi-structured deep interviews. Data collection by interviews is a widely accepted method in sociology and in those subfields of linguistics in which attitudes, stereotypes and ideologies are surveyed (Kvale, 2005; Feischmidt, 2007). Our interview subjects were the leaders of the institutes (directors, education leaders) who possess the power to make decisions, the teachers, the students and their parents.

During the process used to select the data providers and subsequent analysis, we did not bear sociological representativeness in mind, but rather collected a unified text regarding the role language education plays in connection to aspects of identity preservation among Hungarians living in the diaspora, thereby allowing us to receive a comprehensive image of the subject of our research. As a qualitative collection of data, we are unable to totalize statistically the experiences of all the teachers and students or all the schools involved in identity preservation, but we believe that our method can provide a thorough and detailed examination of the research topic due to the depth of the interviews that were conducted. We chose three schools found in three continents by using a geographical sampling technique that was paired with research fieldwork in the case of Cleveland, USA (between October 10, 2017 and October 30, 2017). In all the other cases, the interviews were held during personal meetings in Hungary or online. The interviews were conducted with the help and support of the Pallas Athéné Foundation, the Tempus Public Foundation and the Diaspora Project of the University of Pécs. Throughout the project, altogether ten interviews were carried out in the selected schools with the responsible leaders. Upon summarizing the data, we have formulated our recommendation regarding how Hungarian schools could be brought together with the purpose of furthering each other's work.

\section{The Impact of Language Shift on Hungarian}

Several of the degrees and factors that render languages vulnerable to the effect of a neighboring language are mostly not lingual in nature, but rather a series of external, historical, social, economic, political, and cultural elements that shape the life of a certain ethnic group and its language usage environment (Kloss 1966; Haugen 1972; Bartha 1999 and 2003; Borbély 2001; Fenyvesi 2005; Androutsopoulos 2014; Henry et al 2017). The real threat to a language begins when its demographic, social and political environment changes in a way that results in a loss of the language's actual communicative value, meaning that language's related roles and values become exclusively symbolic (Bartha 2003: 1). Current research emphasizes that those who continue to speak minority languages remain loyal to their language only as long their economic and social circumstances render this possible (Dorian 1981; Edwards 1985; Bartha 2003). Whether a language is retained or not is strongly related to social, economic success; 
Palotai, Jenő, Viktor Wetzl, Ákos Jarjabka. "Identity Preservation and Hungarian Language Education in Diaspora Communities." Hungarian Cultural Studies. e-Journal of the American Hungarian Educators Association, Volume 12 (2019) DOI: 10.5195/ahea.2019.353

however, drawing a direct connection between language preservation and social or economic success is by all means a simplification because the processes actuating with or against other affective factors can be reversed as well (Bartha 2003: 1). In the case of Hungarian minority communities, significant differences must be taken into consideration, such as geographic landscape, settlement types or different groups possessing a strong correlation with the geographical allocation of the language minority, whether it is concentrated, scattered or diaspora-like and with the local ratio of the two, differing language groups as well (Bartha 2003: 2). Although no mutual understanding has been reached regarding this topic (Szépe 1999; Lanstyák et al. 1999), researchers do agree that (due to different factors) the Hungarian language is endangered in the countries which neighbor Hungary since the bilingualism found in the Carpathian Basin's Hungarian communities is typically stable while certain phases of language shift can be found even in homogenous areas (Bartha 2003). This circumstance results in a decrease of the Hungarian language's factual and symbolic function; the number of people speaking the language consequentially decreases while the majority language simultaneously gathers ground. These processes are evident in the scope of Hungarians living in ethnically mixed areas (Szépe 1999; Péntek 2000; Lanstyák 2000; Sándor 2000, Bartha 2003).

The counterpoint to language shift is language preservation, an area that became the focus of research beginning in the 1960s (Fishmann 1966: 424) at the same time as other views emerged urging the cultural and lingual maintenance of bilingual communities (Borbély 2001). While language shift and language preservation are reverse processes, they are nevertheless simultaneously present - at least to varying degrees — in certain communities since both phenomena are connected to social and cultural changes and the relations among language groups (Fishmann 1966; Amastae 1982; Borbély 2001).

\section{Hungarian Language Education in Cleveland, Ohio, USA}

The North American community in Cleveland experienced a different way in the approach to the preservation of the Hungarian identity. The first Hungarian school in Cleveland was opened in 1893 and operated by the Szent Erzsébet [Saint Elizabeth] Hungarian Catholic Church, which was founded in 1892. In the first year, instruction took place for one class taught by one teacher. The school steadily expanded until more than 350 students were being educated in English by 1900, with the help of two nuns from the Orsolya Order. Other than Englishlanguage education, Hungarian and Bible classes were taught by the parish priest (Fejös 1991: 7). The number of students also rose continuously due to the fact that between 1871 and 1913 nearly two million Hungarian citizens left their native land primarily for economic reasons (Gazsó 2016: 14) As a consequence, by 1919 the number of enrolled students reached 1,114 (Papp 1981:188).

When the Szent Imre [Saint Emerick] Catholic Church was opened in 1905 in the western area of the city, educating the Hungarian diaspora community was also a joint effort. The parish priest and nuns sent from Hungary taught Hungarian language, history and geography to approximately for 150 students (Gárdosi 2014). The Calvinist Bishopric built its Hungarian church on the east side of Cleveland in 1894. By 1919, six hundred students generally participated in the Saturday and summer holiday Hungarian language and Bible classes. Other than these programs, several other congregations (the Greek Catholic, Hungarian Lutheran Congregation and Jewish Church) provided Hungarian language education in the settlement (Papp 1981; Fejös 1991; Gárdosi 2014). 
Palotai, Jenő, Viktor Wetzl, Ákos Jarjabka. "Identity Preservation and Hungarian Language Education in Diaspora Communities." Hungarian Cultural Studies. e-Journal of the American Hungarian Educators Association, Volume 12 (2019) DOI: 10.5195/ahea.2019.353

While there was no opportunity to do so, a definite need existed among Hungarian immigrants to establish Hungarian schools which would be equal to state-run schools and eventually independent from non-secular schools. An interim solution to this problem was reached when members of the diaspora community organized weekend and holiday education with the help of local, Hungarian churches. The Hungarian Government also promoted this form of education while also stipulating that adequate school buildings be erected by various denominations when new churches were built. (Fejős 1991; Gárdosi 2014).

In order to expand education, the Hungarian government developed a uniform curriculum for schools which was developed by the Julián Association, an organization that was established in 1904 at the initiative of Count Béla Széchenyi. The curriculum specified what kind of material and topics were to be covered and provided a thorough, pedagogical guideline which enabled Hungarians living in the diaspora to receive the following curriculum: Hungarian language (oral expression, comprehension practice, reading, writing, grammar), the history of the Hungarian nation, constitution studies, the geography of Hungary, singing (folk and religious songs). The tutors had to use the textbooks and reference materials written for elementary schoolchildren living in Hungary (Fejös 1991: 12.; Gárdosi 2014). The Hungarian diaspora in Cleveland quickly expressed the opinion that a greater need existed for textbooks that had been designed specifically for American Hungarian schools since second- and third-generation Hungarians possessed a different type of attachment to their country of origin compared to Hungarian society in general (Fejős 1991; Gárdosi 2014).

The Hungarian migration swelled in numbers during the 1940s when hundreds of thousands of Hungarians left the country in three waves of migration that occurred in less than two decades, yet too place at different times and displayed varying characteristics. The first wave consisted of the soldiers, prisoners of war and deportees who managed to escape abroad during World War II and did not intend to return home. Those who escaped the Soviet Army were also included in this initial mass migration. The second wave occurred during the years preceding the emergence of state socialism and comprised the representatives and supporters of a democratic system. The third was catalyzed by the defeat of the 1956 Hungarian Revolution (Gazsó 2016: 19), at which point more than 200,000 Hungarians left Hungary as political refugees both during the revolution and following its defeat (Murber, 2016). A significant proportion of the migration that occurred between Hungary and the United States of America consisted of the dipik, the Hungarian expression for D.P., or Displaced Persons; more than 360,000 people migrated to the USA (Gazsó 2016) after the war, even though Hungary had fought on the side of Germany. After the 1956 Revolution, roughly 200,000 individuals left Hungary and became known as the " $56 \mathrm{er}$ Hungarians" in the diaspora; a significant proportion of these individuals left Hungary between 1956 and 1957. Most of them moved the USA, totaling the approximate number of 40,000 people (Gazsó 2016).

Within the state of Ohio, Hungarians mostly arrived in significant numbers in the city of Cleveland, meaning that Hungarian education and schools not only continued to be needed but also had to be expanded. Due to this circumstance, the Hungarian Central Textbook Committee was formed in 1958 for the purpose of supervising the maintenance of two Hungarian schools in Cleveland. Under the leadership of János Palasics in East Cleveland and that of Fréda B. Kovács in West Cleveland, adult education was carried out in two different parts of the city. On a weekly basis Hungarian language courses were organized for second- and third-generation, young students who could already barely speak Hungarian (Somogyi 1989). In 1962 the Sándor Remenyik Hungarian Language School of the Cleveland Warriors of Independence Circle was 
Palotai, Jenő, Viktor Wetzl, Ákos Jarjabka. "Identity Preservation and Hungarian Language Education in Diaspora Communities." Hungarian Cultural Studies. e-Journal of the American Hungarian Educators Association, Volume 12 (2019) DOI: 10.5195/ahea.2019.353

formed in the scout home located on the city's eastern side where an average of sixty to seventy students learned Hungarian throughout a seven-year period. In 1969 the school in the Buckeye district (the Hungarian district in Cleveland during the first half of the 1900s) was reorganized and given the new name of Géza Gárdonyi Hungarian School.

In the beginning, the center of Hungarian-language education was the Scout home; later this role was taken over by the Harvey Rice Library and the Lutheran church. Other than these locations, at the initiative of the Saint Margaret [Szent Margit] Roman Catholic parish another Hungarian school was organized where language education was held on Sunday mornings. Later these programs were supplemented with a lecture series in Hungarian Studies held by Professor Ferenc Somogyi (Szentkirályi 2013; Gárdosi 2014). In 1958 the Cleveland Hungarian School was formed under the management of Gábor Papp, Sr. and with the primary aim of educating immigrants who had left Hungary after 1945 or 1956 in Hungarian. The establishment of the school was (and still is) strongly connected to the Scout movement. The aim for its establishment was to involve Cleveland's Hungarian diaspora in the work of the Scouts and continue this effort while rescuing the state of Hungarian Christian national consciousness and preserving the Hungarian language and culture for future generations (Szentkirályi 2008). Initially, the majority of students came from Hungary and therefore only needed instruction in materials connected to Scout training since they already knew the language. Nevertheless, with the passing of time the language background of Hungarians living in the diaspora changed, thereby requiring alterations in the content of the curriculum as well (Németh 2008; Gárdosi 2014). The school began to operate from a private home and only had thirty-six students who studied basic knowledge regarding the Hungarian language and culture. Later, the site of the program was moved to the Scout home, then to the Greek Catholic parish followed by the Lutheran church on the west side of Cleveland, where the Lutheran congregation shared the same location with the Calvinist one.

Throughout the first twenty years of the Hungarian School more than six hundred students studied Hungarian (Somogyi 1989: 10-11; Gárdosi 2014). The educational system was reformed by Ödön Szentkirályi, who became director in 1988 and revised and systematized the school's curriculum and teaching system. The curriculum included the Scoutmaster and instruction in adjutant training as well, thereby furthering the Scout program since the school additionally adopted the teaching material for Scout manager training as well. They also planned to teach Hungarian geography and history from a more global perspective (Tálas 2015).

Hungarian education currently takes place on Monday evenings in the lecture rooms of Szent Imre Catholic Church as well as in the Scout house under the management of Judit Szentkirályi, who instructs both children and adults. The curriculum is supplemented with the material used for Friday-night Scout meetings and the Tuesday-night folk dance group, Regös (Gárdosi 2014). The school is maintained via contributions from the parents and the teachers are volunteers. The teachers are Scouts, local Cleveland diaspora members, Hungarian scholars visiting by means of either the Körösi Csoma Sándor Program or a Fulbright grant and the priest of Szent Imre Catholic Church. Neither a degree in education nor certification as a teacher is needed in order to educate students (Gárdosi 2014).

During the 2017/2018 academic year, the Hungarian School has provided classes for eleven groups, including three pre-school groups, seven classes for school-age students, Scoutmaster courses and one adult group. Each class has a separate tutor. Children between the ages of four and six attend the three pre-school groups (A, B and Basic). In group A, children aged between four and five learn games, counting rhymes, chants and songs in Hungarian other than watching Hungarian-language cartoons or using coloring and cut-and-paste books. Group B 
Palotai, Jenő, Viktor Wetzl, Ákos Jarjabka. "Identity Preservation and Hungarian Language Education in Diaspora Communities." Hungarian Cultural Studies. e-Journal of the American Hungarian Educators Association, Volume 12 (2019) DOI: 10.5195/ahea.2019.353

includes children from ages five to six and employs similar topics and methods that are supplemented with learning the ABC's. At the end of the year an evaluation is prepared regarding each child's progress. While English is sometimes used to explain the material to preschool groups, the teachers aim to be able to use Hungarian throughout the entire course.

The Basic group provides Hungarian language instruction for children who do not speak Hungarian at all and thereby avoids the issue of having different levels of language competency among the children (Gárdosi 2014; Magyar Iskola Cleveland 2017). After graduating in the seventh year, students can attend the Scoutmaster course which is organized by both the school and the Scouts. During this course students who are thirteen to fourteen years old have the opportunity to broaden their knowledge with the inclusion of literature, history and geography lessons found in the textbook and exercise book published by the Foreign Hungarian Scout Association (FHSA). Similar to the classes, students additionally have to memorize poems in this course as well. At the end of the year students take exams compiled by the FHSA; successful students receive the rank of Scout Manager in their scout groups (Szentkirályi 2008; Gárdosi 2014).

Since 2002 the teaching of Hungarian as a foreign language has also been available in the Cleveland Hungarian School and is typically offered to adults of Hungarian origin who wish to participate. At first, tutors tried to use the textbook entitled Halló, itt Magyarország [Hello, Hungary Speaking!] but based on their experience the book presented difficulties for the students since it is only in Hungarian and lacks English-language explanations. The tutors therefore use their own materials. For the beginners the greatest challenge was pronunciation and spelling (Gárdosi 2014).

While conducting their field work, the authors of this study observed that the leaders, tutors, students and parents devoted a great amount of attention and energy to fulfilling as many, comprehensive activities geared toward the preservation of a Hungarian identity as possible while simultaneously instructing students in language. As a vehicle for learning language students memorize numerous Hungarian poems; during Hungarian national holidays both students and the Scouts prepare programs for the Hungarian community. The Hungarian School enjoys good relations with several local Hungarian organizations (Hungarian churches, Scouts, folk dance groups etc.) they can rely upon for aid in satisfying the local Hungarian community's demand to preserve their heritage.

\section{Language Education in the Hungarian Community School, Adelaide, Australia}

In Australia the number of Hungarians living in the diaspora is quite significant and roughly equates between 67,000 and 68,000 people who primarily live in Sydney, Melbourne, Adelaide and the agglomerations surrounding these cities (Gazsó 2016). The migration to the continent started at a later time compared to the United States of America and only encompassed a greater number beginning in the mid-fifties (Kuncz 1997). After World War II, in Australia Hungarian refugees not only felt the need to educate their children in their native language, but also had the opportunity to do so.

According to the Australian education system, the Hungarian Community School in Adelaide is categorized as an ethnic school. This type of institution generally consists of a nonprofit language and cultural center that is accessible to everyone. It is an expectation that the schools should provide at least two hours of instruction per week to students with the aim of language education, sustaining the different cultures of Australia's communities and facilitating cultural understanding and harmony. Students are usually school-age children, but numerous 
Palotai, Jenő, Viktor Wetzl, Ákos Jarjabka. "Identity Preservation and Hungarian Language Education in Diaspora Communities." Hungarian Cultural Studies. e-Journal of the American Hungarian Educators Association, Volume 12 (2019) DOI: 10.5195/ahea.2019.353

ethnic schools educate pre-school children or adults (Department of the Premier and Cabinet, 2017).

The Hungarian Community School in Adelaide was founded by Dr. Ákosné Nagy in 1958 with the aim of preserving Hungarian identity by teaching Hungarian culture, folk dance and language for families who had fled to Australia as refugees in the wake of the 1956 Revolution. In the 1990s the leadership of the school was supplied by János Herendi, who was later followed by Mária Nagy, Annamária Bánházi and Ilona Lelkes. Based on the available opportunities as well as the Australian educational regulation's, students practicing for high school graduation also joined the school led by Sebestyén Maglai and Annamária Bánházi (Szabó 2017; Palotai, Szabó, Jarjabka 2017) at this time. The present number of enrolled students is displayed in the following table.

Table 1: The number of students at the Hungarian Community School in Adelaide from 2001 to 2016 (individuals)

\begin{tabular}{|l|l|l|l|l|l|l|}
\hline Year & $\begin{array}{l}\text { Pre- } \\
\text { school } \\
\text { students }\end{array}$ & $\begin{array}{l}\text { Prep } \\
\text { school } \\
\text { students }\end{array}$ & $\begin{array}{l}\text { Elementary } \\
\text { school } \\
\text { students }\end{array}$ & $\begin{array}{l}\text { Secondary } \\
\text { school } \\
\text { students }\end{array}$ & Adults & Total \\
\hline $\mathbf{2 0 0 1}$ & 0 & 0 & 21 & 4 & 1 & 26 \\
\hline $\mathbf{2 0 0 2}$ & 0 & 0 & 18 & 4 & 0 & 22 \\
\hline $\mathbf{2 0 0 3}$ & 0 & 0 & 13 & 10 & 10 & 33 \\
\hline $\mathbf{2 0 0 4}$ & 1 & 0 & 9 & 6 & 7 & 23 \\
\hline $\mathbf{2 0 0 5}$ & 1 & 0 & 15 & 11 & 3 & 30 \\
\hline $\mathbf{2 0 0 6}$ & 4 & 1 & 15 & 8 & 0 & 28 \\
\hline $\mathbf{2 0 0 7}$ & 3 & 2 & 9 & 0 & 0 & 14 \\
\hline $\mathbf{2 0 0 8}$ & 0 & 2 & 5 & 5 & 0 & 12 \\
\hline $\mathbf{2 0 0 9}$ & 0 & 4 & 5 & 1 & 0 & 10 \\
\hline $\mathbf{2 0 1 0}$ & 0 & 5 & 5 & 3 & 0 & 13 \\
\hline $\mathbf{2 0 1 1}$ & 3 & 0 & 12 & 5 & 0 & 20 \\
\hline $\mathbf{2 0 1 2}$ & 3 & 2 & 21 & 1 & 15 & 42 \\
\hline $\mathbf{2 0 1 3}$ & 5 & 2 & 12 & 2 & 10 & 31 \\
\hline $\mathbf{2 0 1 4}$ & 5 & 3 & 13 & 4 & 15 & 40 \\
\hline $\mathbf{2 0 1 5}$ & 3 & 0 & 10 & 7 & 0 & 20 \\
\hline $\mathbf{2 0 1 6}$ & 0 & 0 & 2 & 15 & 3 & 20 \\
\hline Total & 28 & 21 & 185 & 80 & 64 & 384 \\
\hline Ratio & $7,3 \%$ & $5,5 \%$ & $48,2 \%$ & $20,8 \%$ & $16,7 \%$ & $100 \%$ \\
\hline
\end{tabular}

Source: Palotai, Szabó and Jarjabka. 2017. "The Identity Preserving Efforts of the Hungarian Diaspora in Australia Through the Example of the Hungarian Community School in Adelaide," Civil Szemle 14: 96. 
Palotai, Jenő, Viktor Wetzl, Ákos Jarjabka. "Identity Preservation and Hungarian Language Education in Diaspora Communities." Hungarian Cultural Studies. e-Journal of the American Hungarian Educators Association, Volume 12 (2019) DOI: 10.5195/ahea.2019.353

The number of elementary students is the highest with a proportion of more than $50 \%$, a factor which suggests that this is the age when parents start to familiarize their children more deeply with their heritage. Respectively, the ratio of pre-school students (7.3\%) and prep school students $(5.5 \%)$ is smaller; the values for these groups stagnated during the research period examined in this study, an indication that this trend is most likely due to assimilation and mixed marriages. The number of students in adult classes also grew significantly; $67 \%$ of these students have been learning Hungarian since 2011 (see Table 1). A similar increase was also seen in the case of pre-school students, out of which $68 \%$ started to learn Hungarian following the introduction of the 2010 Simplified Citizenship Act. It is obvious that modifying this act had a positive impact on the Hungarian language learning habits of the Hungarian diaspora in the Southern Australian region (Palotai, Szabó and Jarjabka 2017).

According to Australian regulations, on the national level a minimum of fifteen students need to register for the exam in order to maintain the opportunity to hold an ethnic school, a requirement that presents a serious hurdle for Hungarian schools. In her investigation of this issue, Ágnes Szabó made the following conclusions: while it is understandable that the local schools have an adequate number of students, when they reach graduation, they do not register for the language exam. It is also a problem that the Saturday morning timetable of the weekend schools runs up against that of sports programs or other afternoon students' programs. The Hungarian Community School in Adelaide has also had to face with these problems; in order to remain operating in 2010, they had to find Hungarians who would be able to graduate successfully. In that year they managed to find five students, but this was not enough for the fifteen students required on the national level (Palotai, Szabó and Jarjabka 2017: 98).

As a result of a strong marketing campaign, in 2011 five adult students applied for the graduation process in Adelaide and the total number of graduating students increased to twentyseven in the country. Based on this we can conclude that disinterest is not a factor in the obstacles Hungarian-language education faces and a certain stratus of adults of Hungarian-origin adults who had not had the opportunity earlier to graduate in Hungarian would be furthermore prepared to expand their knowledge. Unfortunately, these adult students could only take advantage of this opportunity for a short period of time since in 2012 the Government of the Province of South Australia maximized the age of the graduating students at twenty-one years. The consequence of this regulation made itself felt in the number of applicants; in 2012 and in 2013 only one student graduated each year in Adelaide (Palotai, Szabó and Jarjabka 2017).

Partly in an attempt to ward off the impacts resulting from the AMPE, the Hungarian Teachers Association of Australia was established in 2013 and already represented themselves in 2015 at the Diaspora Council. The membership thought that it would be worth introducing elearning methods to supplement more traditional didactic and pedagogical methods. In 2014 the Hungarian Community School in Adelaide experimented with using distance learning methods among their own students which led to an increase in the number of student one year after its introduction in 2015, as illustrated in Table 2 (Palotai, Szabó and Jarjabka 2017).

As of 2015 the school already had seven secondary school students who were specifically prepared for graduation. Out of the enrolled students two were from Queensland and one from Western Australia where the students were educated via Skype in cooperation with the Szivárvány (Rainbow) School which educates elementary school students on the Gold Coast. In 2016 the school had fifteen students preparing for graduation, out of which ten individuals were participating from other provinces thanks to online education. In 2016, other than the weekly one hour provided by the community school, Hungarian as foreign language students from Károli 
Palotai, Jenő, Viktor Wetzl, Ákos Jarjabka. "Identity Preservation and Hungarian Language Education in Diaspora Communities." Hungarian Cultural Studies. e-Journal of the American Hungarian Educators Association, Volume 12 (2019) DOI: 10.5195/ahea.2019.353

Gáspár University of the Reformed Church taught at the school under the management of Dr. Orsolya Nádor and with the help of Skype. In 2017 ten online students were enrolled from other provinces; the school presently has six students, a fact that confirms how adequate communication and education methods can be successful. Lastly, the Community School's 2014 initiative of the Community School deserves mention due to the additional incentive that was added to the school's profile: students who apply for graduation were able to study as exchange students at the Reformed Grammar School of Kiskunhalas in Hungary, an effort the the István Bibó Grammar School joined as well in the autumn of 2017. To list the number of students who took advantage of the opportunity to study in Hungary: in 2014 three students from Melbourne while one student from Melbourne and another from Adelaide did the same in 2015. One student traveled to Hungary in 2016 from Adelaide and in 2017 one student from Adelaide and two from Melbourne arrived in Kiskunhalas to develop their Hungarian language knowledge within the framework of the program (Szabó 2017).

Table 2: The composition of the students preparing for graduation and who graduated in the Hungarian Community School in Adelaide (by person)

\begin{tabular}{|c|c|c|c|c|c|c|}
\hline & Provinces & 2015 & 2016 & 2017 & $2018^{I}$ & Total \\
\hline \multirow{6}{*}{$\begin{array}{l}\text { Enrolled } \\
\text { students }\end{array}$} & South Australia & 4 & 5 & 6 & 2 & 17 \\
\hline & Queensland & 2 & 2 & 2 & 2 & 8 \\
\hline & Western Australia & 1 & 1 & 1 & 2 & 5 \\
\hline & Victoria & 0 & 1 & 1 & 0 & 2 \\
\hline & Northern Territory & 0 & 1 & 1 & 0 & 2 \\
\hline & New South Wales & 0 & 5 & 5 & 4 & 14 \\
\hline \multicolumn{2}{|l|}{ Total: } & 7 & 15 & 16 & 10 & 48 \\
\hline \multicolumn{2}{|c|}{ Number of graduating students: } & $\mathbf{0}$ & 1 & 3 & 7 & 11 \\
\hline
\end{tabular}

${ }^{1}$ The number of enrolled students at the start of the year in January will probably be higher.

Source: Palotai, Szabó and Jarjabka Á. 2017: “The Identity Preserving Efforts of the Hungarian Diaspora in Australia Through the Example of the Hungarian Community School in Adelaide," Civil Szemle, 14: 99.

As far as maintaining the organization's infrastructure is concerned, finding adequate finances as well as ensuring that volunteers possess adequate electronic educational competences is crucial to creating a native language environment. Supporting language education with the aid of digital means has led to the formation of virtual communities, a factor that can significantly contribute to the preservation of identity among the diaspora, even in the case of isolation. At the same time sustaining these emerging relationships has evolved into a continuous activity that is conducted with the help of the online, smart devices.

Adult education and new education methods, such as e-learning, also have a role in the preservation of the double, Australian Hungarian identity as well as a Hungarian identity. Elearning is of vital importance due to the great distances that characterize Australia; nevertheless, different regulations that govern education in the provinces together with peculiar school policies 
Palotai, Jenő, Viktor Wetzl, Ákos Jarjabka. "Identity Preservation and Hungarian Language Education in Diaspora Communities." Hungarian Cultural Studies. e-Journal of the American Hungarian Educators Association, Volume 12 (2019) DOI: 10.5195/ahea.2019.353

place obstacles before this type of teaching method. Only learning the Hungarian language is less of an incentive since attaining Hungarian citizenship is the main motivator in adult education. In the case of the young generation, other than the factor of community building (such as scouts), the increased value gained by graduation is a motivating factor, not to mention that attending Hungarian lessons replaces some subjects in the curriculum while additionally providing extra points at the university prelim (Palotai, Szabó and Jarjabka 2017).

The attitude new immigrants demonstrate toward their Hungarian identity is completely different from the idealized mother country image typically found among second- and thirdgeneration Hungarians and even in some cases it is the opposite, meaning that recent arrivals usually don't want to participate in traditional activities. In other words, it cannot be forgotten that a certain part of Hungarian immigrants chose Australia due to existential pressure, a factor that explains their tendency to adapt, assimilate, establish their own financial safety and the goal of improving their knowledge of English. Striving toward these aims frequently lessens the amount of energy put toward maintaining a Hungarian identity. Time and opportunity are therefore needed in order for these families to reconnect with their Hungarian origins and the community. In short, a completely different educational program should be constructed for the children originating from families who have recently immigrated to Australia since the majority of these individuals speak Hungarian; in this case, focus should instead be placed on writing, reading and the expansion of their vocabulary.

\section{Language Education in the Hungarian School of São Paolo, Brazil}

In Latin America, the Hungarian diaspora displays high numbers totaling high roughly 125,000 people, with the largest proportion found in Brazil (75,000 individuals) and Argentina (40,000 individuals). Hungarian cultural life is mostly concentrated around São Paulo and Buenos Aires (Gazsó, 2016). In São Paulo the institutional establishment of Hungarian language education took place in 2015 within the framework of a Hungarian language and culture course held at the Universidade de São Paulo (USP).

The need to learn Hungarian and the make-up of Hungarian language education can be unequivocally connected to the introduction of the 2010 law that ensures an expedited process for acquiring Hungarian citizenship. One precondition for passing the citizenship application process is the ability to conduct a conversation with the consul that displays fluent language abilities. As a matter of fact, the expected level of language usage can easily be achieved by completing ten to fifteen language lessons. In 2014 the language prerequisite changed; applicants could only meet the consul after having attended Hungarian language lessons for at least half of a year. By 2015 this requirement was toughened even further: at least one-and-a-half years had to be spent learning Hungarian before a meeting could be conducted with the consul.

The Brazilian Hungarian diaspora expressed a demand for the institutionalized learning of Hungarian, a need that subsequently led to the emergence of the aforementioned course in language and culture. During the first lesson, students are informed that the main aim of the course is not to provide a quick preparation for meeting with the consul, but rather to acquire knowledge of Hungarian while gaining an extensive familiarization with Hungary's culture, a factor that supports integration into Hungary. The curriculum teaches appropriate language use, requires writing and reading skills, explores numerous topics for the purpose of expanding the students' vocabulary and additionally includes aspects of cultural knowledge; in other words, students are expected to learn far more than what is expected when meeting with the consul. The make-up of the number of students has been displayed in Table 3. 
Palotai, Jenő, Viktor Wetzl, Ákos Jarjabka. "Identity Preservation and Hungarian Language Education in Diaspora Communities." Hungarian Cultural Studies. e-Journal of the American Hungarian Educators Association, Volume 12 (2019) DOI: 10.5195/ahea.2019.353

Table 3: The number of enrolled students and successful examinees at the University of São Paulo between 2015 and 2017.

\begin{tabular}{|l|l|l|l|}
\hline Enrolled & $\mathbf{2 0 1 5}$ & $\mathbf{2 0 1 6}$ & $\mathbf{2 0 1 7}$ \\
\hline $\begin{array}{l}\text { Successful } \\
\text { examinees }\end{array}$ & 254 & 266 & 247 \\
\hline $\begin{array}{l}\text { The ratio of } \\
\text { successful } \\
\text { examinees }\end{array}$ & $67,3 \%$ & 207 & 196 \\
\hline
\end{tabular}

Source: based on USP data own editing

While the number of students enrolled in Hungarian training is stagnating, the ratio of successful examinees (the ultimate aim of the course) displays a steady increase. Based on their language competences, students were divided into the beginner-, intermediate- and advancedlevel groups. As most students attend the beginner group, it became necessary to divide the groups even further. The curriculum targets the acquisition of Hungarian while providing extensive exposure to Hungarian culture; as a result, this course assists integration into Hungary. Throughout their education, students study from MagyarOk, the textbook developed by Szilvia Szita and Katalin Pelcz, director of the International Education Centre of the Medical School at the University of Pécs. Other than this source, the Library of the University of Pécs ensures a supply of relevant books in Hungarian (own data collection, 2017).

The Hungarian course at the Universidade de São Paulo provides students with longterm, in-depth knowledge that will allow them to manage life in Hungary. Since the students who opt to learn Hungarian are not only motivated by the opportunity to attain Hungarian citizenship, a broader picture can be obtained regarding the students' general interest and motivation by examining various opportunities to achieve scholarships. It cannot be denied that the ability to receive a scholarship for studying in Hungary unequivocally contributes to the desire to receive Hungarian citizenship as well (own data collection, 2017).

A common aim unites the four institutions offering language instruction that have been examined in this study: maintaining Hungarian identity in addition to preserving traditions and the identity of subsequent generations of Hungarian descent. In spite of this mutual goal, the methodology employed by each institution significantly differs from one another as regards both teaching material and didactic methods. Table 4 illustrates as well as summarizes these differences by comparing the Hungarian schools based on several aspects. 
Palotai, Jenő, Viktor Wetzl, Ákos Jarjabka. "Identity Preservation and Hungarian Language Education in Diaspora Communities." Hungarian Cultural Studies. e-Journal of the American Hungarian Educators Association, Volume 12 (2019) DOI: 10.5195/ahea.2019.353

Table 4 A comparison of the schools in Adelaide, Cleveland and São Paulo

\begin{tabular}{|c|c|c|c|}
\hline & $\begin{array}{l}\text { Adelaide Community } \\
\text { School }\end{array}$ & $\begin{array}{l}\text { Cleveland Hungarian } \\
\text { School }\end{array}$ & Universidade de São Paulo \\
\hline Teachers & volunteer & Volunteer & university tutors \\
\hline $\begin{array}{l}\text { Student age } \\
\text { groups }\end{array}$ & all age groups are present & $\begin{array}{l}\text { from the age of } 5 \text { to } 14-15 \\
\text { years and also adult } \\
\text { education }\end{array}$ & adult education \\
\hline Motivation & $\begin{array}{l}\text { identity preservation, } \\
\text { acquisition of Hungarian } \\
\text { citizenship }\end{array}$ & identity preservation & $\begin{array}{l}\text { acquisition of Hungarian } \\
\text { citizenship, identity } \\
\text { preservation, studying in } \\
\text { Hungary }\end{array}$ \\
\hline $\begin{array}{l}\text { Teaching } \\
\text { Methodology }\end{array}$ & $\begin{array}{l}\text { own materials, preparatory } \\
\text { textbook for the Australian } \\
\text { Hungarian graduation, } \\
\text { education via Skype }\end{array}$ & $\begin{array}{l}\text { textbooks published by the } \\
\text { Balassi Institute, textbook } \\
\text { issued by the Hungarian } \\
\text { Scouts, memorization of } \\
\text { poems }\end{array}$ & $\begin{array}{l}\text { textbook entitled MagyarOk, } \\
\text { textbooks provided by the } \\
\text { Library of the University of } \\
\text { Pécs }\end{array}$ \\
\hline Partner institutes & $\begin{array}{l}\text { University of Pécs, Körösi } \\
\text { Csoma Sándor Program of } \\
\text { the Hungarian Government, } \\
\text { Rákóczi Association, Károli } \\
\text { Gáspár University, Kőrösi } \\
\text { Csoma Sándor Cultural } \\
\text { Circle, Ethnic School } \\
\text { Association }\end{array}$ & $\begin{array}{l}\text { Hungarian Scouts in } \\
\text { Cleveland, Hungarian } \\
\text { churches, Regös Folk Dance } \\
\text { Group, Foreign Hungarian } \\
\text { Scout Association, Balassi } \\
\text { Institute }\end{array}$ & $\begin{array}{l}\text { University of Pécs, Pallas } \\
\text { Athene Domus Animae } \\
\text { Foundation, Magyar Ház }\end{array}$ \\
\hline $\begin{array}{l}\text { Activities for } \\
\text { tradition } \\
\text { preservation }\end{array}$ & $\begin{array}{l}\text { traditions preserved by } \\
\text { holding of festivities, } \\
\text { education in Hungarian } \\
\text { cultural knowledge }\end{array}$ & $\begin{array}{l}\text { tradition preserved on a } \\
\text { regular basis together with } \\
\text { the scouts, the churches and } \\
\text { folk-dance group }\end{array}$ & $\begin{array}{l}\text { tradition preserved by } \\
\text { holding of festivities, } \\
\text { education in Hungarian } \\
\text { cultural knowledge }\end{array}$ \\
\hline
\end{tabular}

Source: Palotai, Szabó and Jarjabka Á. 2017: "The Identity Preserving Efforts of the Hungarian Diaspora in Australia Through the Example of the Hungarian Community School in Adelaide," Civil Szemle, 14: 99.

How these education programs came to be initiated in the three schools fundamentally differs from one another, a factor that can be explained by the different time periods during which Hungarians arrived in their destination country. In the case of North America and Latin America, for instance, Hungarians arrived earlier, therefore the preconditions needed for language education were also established earlier. Language education in Cleveland was effectuated and operated with the help of religious organizations, while the school in Adelaide started at the initiative of private citizens. Hungarian language education in São Paulo is operated by the local university with the support of the Pallas Athene Domus Animae Foundation and the University of Pécs. While Hungarian schools in Adelaide and in Cleveland were established in 1958, Cleveland had a distinct advantage due to the fact that instruction in Hungarian has been 
Palotai, Jenő, Viktor Wetzl, Ákos Jarjabka. "Identity Preservation and Hungarian Language Education in Diaspora Communities." Hungarian Cultural Studies. e-Journal of the American Hungarian Educators Association, Volume 12 (2019) DOI: 10.5195/ahea.2019.353

present in this city for sixty-five years. To mention just a few variables, this advantage is evident in the education materials, infrastructure and the experiences as well. In contrast, language education at the Universidade de São Paulo is rather new since it was only launched in 2015. A significant part of the present Hungarian diaspora can be found on the American continent (Gazsó, 2016), therefore the school in Cleveland can rely on a greater basis compared to the program in Adelaide. The Australian school established its online education courses by eliminating the quantity and spatial barriers, a step that enabled them to increase the number of enrolled students. In Cleveland, education is conducted in a brick-and-mortar school building, although the school has also recently tried online education, an experiment that did not prove successful. The reason for this is that Hungarian language education is characteristically present in those American cities possessing a Hungarian community as well. In São Paulo education is carried out at the Universidade de São Paulo where students' primary motivation differs from that exhibited by those enrolled in the other schools under discussion since their main aim is to attain Hungarian citizenship or continue studying in Hungary, goals which can only be achieved by completing a successful conversation with the consul.

The make-up of the schools' student body also varies. Throughout its education programs, the Adelaide Hungarian Community School covers all age groups, while in Cleveland preschool and school children are taught until the ages of thirteen or fourteen, together with adult education. In São Paulo mainly adults avail themselves of Hungarian language courses. Nevertheless, it is also important to mention that in Cleveland numerous other Hungarian organizations exist beyond the school that are not only visited by adults, but also comprise sites where usage of Hungarian is required. This allows attendees to develop their vocabulary while maintaining language ability as well. Furthermore, the end result attained by these programs also differs; in Adelaide the main aim of the school (beyond that of teaching Hungarian) is for students to gain a Hungarian graduation certificate, as established by the Australian state. In Cleveland the expected outcome is for students to finish the scout leader course at the Foreign Hungarian Scout Association. Similar to the university exam system, in São Paulo the requirement for students to complete exams at the end of each semester, while the final result is the students' strong motivation to acquire Hungarian citizenship.

Based on our research we can conclude that the main aim of the educational institutions examined in this study is to teach the Hungarian language to newer generations of the Hungarian diaspora and thereby strengthen and the preserve a Hungarian identity. This latter aim, however, is reached by means of different approaches, measures and methods. We can detect differences in the scope of the students as well which can mainly be explained by the number and size of the given diaspora. Notwithstanding this aspect, all the investigated schools make enormous efforts to sustain the teaching of the Hungarian language and thus transmit the Hungarian language, identity and traditions to future generations.

As the conclusion of our research, we can state that the greatest current challenge surrounds succession and transmission, issues which are not only faced by Hungarian communities, but also by every diaspora population. The fact that the surrounding language and environmental factors affect both the national culture and assimilation is in many cases inevitable. During our research, data providers expressed the thought that they are in a lucky position since a demand for the Hungarian language and culture has been adequately exhibited among the younger members of the community as well.

The visualization and maintenance of the domestic culture cannot exist without an adequate infrastructural and organizational system. Our research proved that the examined 
Palotai, Jenő, Viktor Wetzl, Ákos Jarjabka. "Identity Preservation and Hungarian Language Education in Diaspora Communities." Hungarian Cultural Studies. e-Journal of the American Hungarian Educators Association, Volume 12 (2019) DOI: 10.5195/ahea.2019.353

settlements are in a privileged situation since they contain organized Hungarian cultural institutions that provide as many opportunities as possible for the preservation and transmission of the origin country's culture. Naturally, an adequate financial background is also needed for the management of these institutions. Establishing and sustaining financial safety is not a significant problem for these institutes since their financial security is ensured by support from both civilian sources and the Hungarian state.

As a further direction for our research, we would like to suggest that all schools, institutions and organizations offering instruction in Hungarian culture should be organized in a cultural cluster that would thereby enable the transfer of knowledge transfer among these institutions. An opportunity such as this would provide the chance to share educational materials, methods and engender further development as well. In this case a significant step forward in the teaching of Hungarian and the preservation of Hungarian culture in the diaspora would be the expected outcome. In our opinions, the Diaspora Project Network at the University of Pécs could form an adequate means to group these activities together. Under the aegis of the university, Hungarian-Hungarian workshops that examine issues related to Hungarian language education could be held for the purpose of promulgating best practices and common activities while governmental cooperation could be presented and established in order to plan and sustain the future existence. A long-term subsistence strategy should be planned by the Hungarian institutions of the diaspora for this global Hungarian school network in order to successfully maintain and preserve the Hungarian culture and identity.

\section{Works Cited}

Amastae, Jon. 1982. "Language Shift and Maintenance in the Lower Rio Grande Valley of Southern Texas." In Bilingualism and Language Contact: Spanish, English, and Native American Languages. Eds. Florence Barkin, Elizabeth A. Brandt, Jacob Ornstein-Galicia. New York: Teachers College Press, Columbia UP, 261-277.

Androutsopoulos, Jannis. ed. 2014. "Mediatization and Sociolinguistic Change." Walter de Gruyter GmbH \& Co KG, Vol. 36.

Bartha, Csilla. 1999. A kétnyelvüség alapkérdései: Beszélök és közösségek ['Basic Questions of Bilingualism: Speakers and Communities']. Budapest: Nemzeti Tankönyvkiadó.

--------. 2003. A kisebbségi nyelvek megörzésének lehetőségei és oktatása ['Opportunities and Education for the Preservation of Minority Languages']. http://real.mtak.hu/13812/1/kimenet.pdf Accessed March 16, 2018.

Borbély, Anna. 2001a. Nyelvcsere ['Language Exchange']. Budapest: MTA Nyelvtudományi Intézet.

Borbély, Anna. 2001b. "A nyelvcsere folyamata és kutatása" ['The Process and Research of Language Exchange']. Nyelvtudományi Közlemények 98: 193-215.

Department of the Premier and Cabinet 2017. "Ethnic schools." https://www.sa.gov.au/topics/education-and-learning/schools/choosing-aschool/ethnic-schools Accessed December 14., 2018.

Dorian, Nancy Currier. 1981. Language Death: The Life Cycle of a Scottish Gaelic Dialect. Philadelphia: University of Pennsylvania Press.

Edwards, John. 1985. "Language, Society and Identity.” Oxford: Basil Blackwell. 
Palotai, Jenő, Viktor Wetzl, Ákos Jarjabka. "Identity Preservation and Hungarian Language Education in Diaspora Communities." Hungarian Cultural Studies. e-Journal of the American Hungarian Educators Association, Volume 12 (2019) DOI: 10.5195/ahea.2019.353

Fejős, Zoltán. 1991. “Az anyanyelvi oktatástól az etnikus kultúra átörökítéséig. (Magyar iskolaügy Amerikában 1890 és 1940 között)" ['The Transmission of Ethnic Culture from Mother Tongue Education (Hungarian Schooling in America between 1890 and 1940']. In Magyarságkutatás: A Magyarságkutató Intézet évkönyve 1990-1991: 7-40.

http://kisebbsegkutato.tk.mta.hu/uploads/files/olvasoszoba/magyarsag kutatoevkonyv /evkonyv1990_91.pdf Accessed July 16., 2018.

Fenyvesi, Anna. ed. 2005. "Hungarian Language Contact Outside Hungary: Studies on Hungarians a Minority Language.” John Benjamins Publishing, Vol. 20.

Fishman, Joshua Aaron. 1966. "Language Loyalty in the United States: The Maintenance and Perpetuation of Non-English Mother Tongues by American Ethnic and Religious Groups." Mouton: The Hague.

Gal, Susan. 1979. Language Shift: Social Determinants of Linguistic Change in Bilingual Austria. New York: Academic Press.

------. 1991. Mi a nyelvcsere és hogyan történik? ['What Is Language Change and How Does It Happen?’]. Regio - Kisebbségtudományi Szemle 2/1. 66-76.

Gárdosi, Rita. 2014. "A clevelandi magyar nyelvoktatás múltja és jelene" ['The Past and Present of the Hungarian Language Teaching in Cleveland']. December 22, 2017. http://epa.oszk.hu/01400/01467/00012/pdf/EPA01467_thl2_2014_2_058-067.pdf 22. Accessed December 11, 2017.

Gazsó, Dániel. 2016. “A magyar diaszpóra fejlődéstörténete” ['The Development of the Hungarian Diaspora']. Kisebbségi Szemle 1/1. 9-35.

Grenoble, Lenore and Whaley, Lindsay. eds. 1998. Endangered Languages: Language Loss and Community Response. Cambridge: Cambridge University Press.

Grin, Francois. 1999. "Market Forces, Language Spread and Linguistic Diversity." In Kontra, Mikós et al. 169-186.

Grosjean, Francois. 1982. Life with Two Languages. An Introduction to Bilingualism. Harvard: University Press.

Haugen, Einar. 1972. "The Stigmata of Bilingualism.” In The Ecology of Language: Essays by Einar Haugen. Ed. Answar S. Dil. Stanford: Stanford University Press. 307-344.

Henry, M. Levin, Carroll, Frederick, Cunliffe, Daniel and Kop, Rita. 2017. "Learning a Minority Language Through Authentic Conversation Using an Online Social Learning Method." Computer Assisted Language Learning. 1-25.

Jarjabka, Ákos. 2012. Kultúramenedzselési ismeretek ['Cultural management skills']. Carbocomp Publisher, Pécs.

Kloss, Heinz. 1966. “German-American Language Maintenance Efforts.” In Language Loyalty in the United States. Eds. Fishman, Joshua, Aaron. et. al. The Hague, Mouton. 206-252.

König, Matthias. 1999. "Cultural Diversity and Language Policy." International Social Science Journal 51/161. 401-408.

Krauss, Michael. 1998. "The Scope of the Language Endangerment Crisis and Recent Response to It." In Studies in Endangered Languages. Ed. K. Matsumura. Tokyo: Hituzi Syobo. 108109.

Kuncz, Egon. 1997. Magyarok Ausztráliában ['Hungarians in Australia']. Budapest: Teleki László Alapítvány.

Lanstyák, István, Simon, Szabolcs and Szabómihály, Gizella. 1999. "Nyelvpolitika a kisebbségi oktatásban” ['Language Policy in Minority Education']. Fórum Társadalomtudományi Szemle. 1/1. 89-98. 
Palotai, Jenő, Viktor Wetzl, Ákos Jarjabka. "Identity Preservation and Hungarian Language Education in Diaspora Communities." Hungarian Cultural Studies. e-Journal of the American Hungarian Educators Association, Volume 12 (2019) DOI: 10.5195/ahea.2019.353

Lanstyák, István. 2000. A magyar nyelv Szlovákiában ['The Hungarian Language in Slovakia']. Budapest: Osiris-Kalligram-MTA Kisebbségkutató Mühely.

Maffi, Luisa. 1996. "Proposition Paper for the Interdisciplinary Working Conference "Endangered Languages, Endangered Knowledge, Endangered Environments." http://cougar.ucdavis.edu/nas/terralin/home.html Accessed March 16, 2018.

Magyar Iskola tananyaga 2017. Magyar Iskola Cleveland belsö anyaga ['Teaching Material of Hungarian School 2017. Internal School of Cleveland']. Magyarország Nagykövetsége. http://www.mfa.gov.hu/kulkepviselet/YU/hu/Konzuliinfo/tajekoztato_honositasi_eljarasrol.ht ml Accessed July 1. 2017.

Németh, Szilvia. 2008. Hétvégi magyar iskolák az USA-ban: 2008 (Interjú- és dokumentumelemzés) ['Weekend Hungarian Schools in the US: 2008 (Interview and Document Analysis)']. In Beszédböl világ. Elemzések, adatok amerikai magyarokról. ['From World of Speech. Analyzes, Data about American Hungarians.'] Ed. Attila Z. Papp. Budapest, Magyar Külügyi Intézet. 266-300.

Nora, Pierre. 2003. Emlékezet és történelem között ['Between Memory and History']. Múlt és Jövő, 14/4. 3-16.

Palotai, Jenő, Szabó, Ágnes and Jarjabka, Ákos. 2017. "The Identity Preserving Efforts of the Hungarian Diaspora in Australia Through the Example of the Hungarian Community School in Adelaide." Civil Szemle 14/3. 87-103.

Murber, Ibolya. 2016. “Az 1956-os magyar menekültek Ausztriában: menekültlét és integráció’'['1956 Hungarian refugees in Austria: refugee and integration']. Múltunk 61/3. 123-159.

Papp, M. Susan. 1981: "Hungarian Americans and Their Communities of Cleveland." Cleveland Ethnic Heritage Studies. Cleveland: Cleveland State University.

Péntek, János 2000. A nyelv ritkuló légköre ['The Tearful Atmosphere of Language']. Kolozsvár: Komp-Press.

Sándor A. 2000. Anyanyelvhasználat és kétnyelvüség egy kisebbségi magyar beszélöközösségben, Kolonban ['Use of Mother Tongue and Bilingualism in a Minority Hungarian Speaking Community, Kolon’]. Pozsony: Kalligram.

Skutnabb-Kangas, Tove. 1999. "Linguistic Diversity, Human Rights and the 'Free' Market." In Kontra, Miklós et al. 187-222.

---------. 2000. "Linguistic Genocide in Education: or Worldwide Diversity and Human Rights?” New Jersey: Lawrence Erlbaum.

Somogyi, Ferenc. ed. 1989. Emlékkönyv: Az Egyesült Magyar Alap húszévi müködéséről 1968-1988. ['Memorial Book: Twenty Years of Operation of the United Hungarian Fund 1968-1988.'] Cleveland, Ohio.

Szabó, Ágnes. 2017. "Hungarian Community School Adelaide.” The Ethnic Schools Association of South Australia Inc. December 28, 2017. http://admin.mailo.com.au/t/ViewEmail/r/D0D001E336FBC50F2540EF 23F30FEDED /23EF4B1ABE29A4B063B21DE8DA818551 Accessed December 28., 2017.

Szentkirályi, Endre. 2013. "Hungarians in Cleveland 1951-2001: Then and Now." Doctoral Dissertation. Debreceni Egyetem.

Szentkirályi, Endre ed. 2008. Clevelandben még élnek magyarok? Visszaemlékezések gyüjteménye ['Are Hungarians Still Living in Cleveland? A Collection of Recollections.']. Cleveland: Cleveland Cserkész Regös Csoport. 
Palotai, Jenő, Viktor Wetzl, Ákos Jarjabka. "Identity Preservation and Hungarian Language Education in Diaspora Communities." Hungarian Cultural Studies. e-Journal of the American Hungarian Educators Association, Volume 12 (2019) DOI: 10.5195/ahea.2019.353

Szépe, György. 1999. "The Position of Hungarians in Romania and Slovakia in 1996." Nationalities Papers. 27/1. 69-93.

Tabouret-Keller, André. 1968. "Sociological Factors of Language Maintenance and Shift: A Methodological Approach Based on European and African Examples." In Language Problems of Developing Nations. Eds. Joshua Aaron Fishman, Charles Albert Ferguson and Joytirindra Das Gupta. John Wiley and Sons Inc., New York. 107-118.

Tálas, Tünde. 2015. "Szentkirályi Ödön bácsi mesél a Magyar Iskoláról” ['Uncle Szentkirályi Ödön Tells About the Hungarian School']. Bocskai Rádió, https://www.bocskairadio.org/szentkiralyi-odon-bacsi-mesel-a-magyar-iskolarol/ Accessed December 22., 2017. 